\title{
Ambassador George Buchanan and the July Crisis
}

\section{John W. Young}

\begin{abstract}
During the July Crisis, the United Kingdom was put under strong pressure from Russia and the latter's ally, France, to declare it would fight alongside them. Britain had made the entente cordiale with France in 1904 and a Convention with Russia in 1907. The British Ambassador to St. Petersburg, George Buchanan, was the key figure in diplomatic communication between Britain and Russia at this time and his performance has drawn diverse comments over the decades. Some analysts believe he genuinely sought to restrain Russia from war, but was undermined by his own government, who too easily accepted St. Petersburg must mobilise its army. But others feel Buchanan's reports of Russian mobilisation were ill-informed and unhelpful to the government in London. This article examines Buchanan's performance, arguing that he attempted to preserve peace for a time and does not deserve some of the criticisms levelled at him. Nonetheless, the preservation of the Triple Entente was a priority for him and, after about 28 July, once it became clear that European war could not be avoided, he became tardy in reporting Russia's war preparations, appearing more interested in defending his hosts' behaviour than in providing an accurate analysis of events.
\end{abstract}


In late June 1914, at an embassy dinner in the presence of foreign minister Sergei Sazonov, Britain's ambassador, Sir George Buchanan, expressed confidence that Anglo-Russian friendship had 'taken such root that it will be able to weather all the

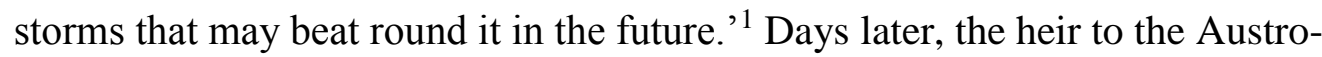
Hungarian throne was assassinated by a Bosnian Serb. Sir Arthur Nicolson, Buchanan's predecessor in Russia, now Permanent Under-Secretary of the Foreign Office (FO), hoped this would 'not lead to any further complications... ${ }^{2}$ But on 23 July, a series of harsh demands was made by the Austro-Hungarian government against its Serbian neighbour. There followed nine days of intense diplomacy - with Russia backing Serbia, while Germany supported Austria-Hungary - before, on 1 August, Germany declared war on Russia, heralding a European conflict. During this time, the United Kingdom was pressed by Russia and the latter's ally, France, to declare it would fight beside them. Britain had made the entente cordiale with France in 1904 and a Convention with Russia in 1907. Both focused on resolving differences in the imperial sphere, but they had serious implications for Europe, where Berlin feared encirclement by the 'triple entente', while Paris and St. Petersburg expected support in diplomatic crises.

Buchanan's performance has drawn diverse comments over the decades. Two early analysts, Harry Barnes and Sidney Fay, believed he genuinely sought to restrain Russia from war, but was undermined by his own government, who too easily accepted that St. Petersburg must mobilise its army. ${ }^{3}$ Recently, however, it has been claimed Buchanan's reports of Russian mobilisation 'were about as ill-informed as diplomatic dispatches could be. ${ }^{4}$ This essay will examine Buchanan's performance, arguing that he attempted to preserve peace for a time and does not deserve some 
criticisms levelled at him. Nonetheless, the preservation of the Triple Entente was a personal priority and, in late July, once it became clear that European war could not be avoided, he became tardy in reporting Russia's war preparations, appearing more interested in defending his hosts' behaviour than in providing an accurate analysis of events. This was significant because, in 1914, in the absence of strong international organisations, with summit conferences (and even foreign ministers' meetings) a rarity and communications relayed by telegraph, ambassadors were highly significant in shaping information flows to their home government and thereby influencing decision-making. British diplomats may have lacked 'the authority and independence which could be accumulated by French ambassadors', but commanded greater respect than their German counterparts, who were, 'with few exceptions, not trusted lieutenants but rather orderlies of superior figures who allowed them little independence...' Nicolson's case confirms Zara Steiner's judgement that Britain's ambassadors were 'restricted in [their] attitudes and interests', but challenges her conclusion that their 'room for manouevre was small and the post-war debate about the responsibility of the diplomats for the outbreak of the war has a curiously artificial air about it. ${ }^{5}$

Buchanan was the key source of information for Britain about Russian intentions during the July crisis. The Russian ambassador in London, Count Alexander Benckendorff, in post since 1902, was an efficient diplomat and an anglophile, well-connected in high society and respected in the Foreign Office. ${ }^{6}$ But he only met with Grey three times after the crisis broke: on 25 and 27 July, he pressed for a warning to Germany that Britain would enter the war; on 30 July he set out Sazonov's position on peace talks, which had already been reported to London by 
Buchanan. Understandably, Benckendorff's priority was to ensure British intervention rather than to provide Grey with objective information. The last was Buchanan's responsibility. $^{7}$

\section{George Buchanan}

It has been said that, with his 'monocle, his finely-chiselled features, and his beautiful silver-grey hair', Buchanan, posted to St. Petersburg in 1910, had 'something of the appearance of a stage-diplomat. ${ }^{8}$ The son of Sir Andrew Buchanan, himself a successful Victorian ambassador, George first served under his father in Vienna in 1876, then gained experience in Germany and Italy, before becoming British envoy to Bulgaria, a post that familiarised him with the intricacies of Balkan politics. The former Permanent Under-Secretary, Lord Hardinge, was confident George would be successful in St. Petersburg, 'as he is a gentleman and quite sensible although not overburdened with brains. ${ }^{9}$ Robert Bruce Lockhart, Acting Consul-General in Moscow, felt Buchanan was 'no Russian scholar' and 'not a man of outstanding intellect... [but] he had remarkable powers of intuition and an abundant supply of common sense. To Russian cleverness he opposed complete honesty and sincerity tempered with caution. ${ }^{10}$ Whatever his cultural separation from the Russians, he remained in St. Petersburg until 1918. A particular success was to build a friendly working relationship with Sazonov. ${ }^{11}$

One of his staff recalled that, 'Both morally and physically [Buchanan] was the soul of modest courage... he kept to a middle register of imperturbable serenity', though he also had an other-worldly quality: 
I don't think Sir George knew what he was eating or drinking himself... He was too deep sunk in thought, thinking over... his morning talk with the Minister for Foreign Affairs, planning his despatches and telegrams.... ${ }^{12}$ This illuminates Michael Hughes' point that Buchanan's 'detached manner was at least in part simply a product of chronic absent-mindedness and shyness. ${ }^{13}$ A less flattering picture emerges from Somerset Maugham, an intelligence officer in wartime Russia who, in his Ashenden stories, based the character of Sir Herbert Witherspoon on Buchanan. When they were first introduced, Ashenden 'was received with a politeness to which no exception could be taken, but with a frigidity that would have sent a little shiver down the spine of a polar bear.' Later, having been invited to dinner, Ashenden 'would have been more interested if the Ambassador had not so invariably said the right, wise and sensible thing upon every topic that was introduced.' Yet, despite repeated references to Witherspoon's coldness, Maugham is clear he was 'not an ordinary person':

He knew how to be determined when determination was necessary and conciliatory when conciliation was opportune. His manners were perfect... he had a clear and logical brain. He was never afraid to think his thoughts out to the end, but was wise enough to suit his actions to the exigencies of the situation. ${ }^{14}$

\section{Anglo-Russian relations in mid-1914}

Despite the 1907 Convention, there were persistent Anglo-Russian tensions, caused by rivalries in central Asia (especially over their relative influence in Persia) and criticism of the authoritarian Tsarist regime from the ruling British Liberal Party. Tsar Nicholas II and Sazonov were disappointed with Britain's lukewarm support during 
the Balkan Wars of 1912-13 and Foreign Secretary Sir Edward Grey's reluctance to transform the entente into a military alliance. Most analysts see Grey as pursuing a balanced approach between Russia and Germany in early $1914^{15}$, although Keith Wilson argues the Foreign Secretary was always likely to side with Russia in a crisis, largely because of the potential threat it posed to British interests in Asia, including India. ${ }^{16}$ Thomas Otte points out there were differences of emphasis within the FO, with Nicolson keen to work closely with St. Petersburg, while the Assistant UnderSecretary, Sir Eyre Crowe, was less willing to overlook Russian excesses in Persia. ${ }^{17}$ In his memoirs, Buchanan was keen to portray himself as a strong supporter of the entente, quoting a February 1914 telegram, in which he said there was 'a good deal of truth in Sazonoff's contention that, if Germany knew beforehand that France and Russia could count on England's support, she would never face the risks which such a war would entail. ${ }^{18}$ Other evidence, however, suggests he was uncertain of Russian goodwill. In March 1914, he warned Nicolson that Russia only needed British support while completing her current armaments programme: 'her eventual attitude towards us will depend on whether we stand firmly by her in any crisis which may arise during the intervening years. ${ }^{, 19}$ But both documents pointed to a belief Britain must stand by its entente partners in any war crisis. This was only to be expected, given that Buchanan's appointment was backed by Nicolson and Hardinge, who were both suspicious of Germany and keen to work closely with Russia. ${ }^{20}$ Furthermore, Lady Buchanan was sister to the $7^{\text {th }}$ Earl Bathurst, owner of The Morning Post, a right-wing daily newspaper that also backed the entente. As the July Crisis broke, its editor believed that, 'Germany thinks her time has come to challenge France and Russia.' ${ }^{21}$ 
Significantly, before the crisis, Buchanan and the FO were hoping to extend the 1907 Convention, a course beset by uncertainty. A tentative agreement by Grey, in April, to open discussions on an Anglo-Russian naval agreement, was a positive sign, but there remained serious differences over Persia. ${ }^{22}$ In early July 1914, the main concern in Anglo-Russian relations was not the assassination at Sarajevo, which initially seemed unlikely to provoke conflict, but the prospect of restoring the Russian entente to good health. This order of priorities is revealed in a letter the Ambassador sent to Nicolson on 9 July. Only at the end did Buchanan comment on Sarajevo, simply remarking, 'Now the first feeling of horror evoked by the assassination... has passed away, the general impression would seem to be one of relief that so dangerous a personality should have been removed from the succession...' The bulk of the letter concerned Anglo-Russian relations in Asia. Buchanan reported that, two days earlier, seeking to allay British fears that Russia might invade India, Sazonov had raised the idea of a mutual Anglo-Russian guarantee of the inviolability of their Asian possessions. To prevent Japan - a British ally since 1902 - being offended by this, he was willing to bring Tokyo in to a tripartite guarantee. The Ambassador was so taken aback by this unexpected offer, he doubted Sazonov's seriousness. Buchanan also told Nicolson of France's keen desire to resolve differences over Persia between their entente partners. The French ambassador, Maurice Paléologue, had said President Raymond Poincaré, who was due in St. Petersburg for a state visit on 20 July, would make it 'one of the chief subjects of conversation' with the Russians. ${ }^{23}$ On 19 July, Sazonov repeated the offer of a tripartite Anglo-Russian-Japanese guarantee; Grey told Buchanan he was 'personally attracted' to this, but could only pursue it when 'the Parliamentary and Irish situation' gave time to do so. ${ }^{24}$ 
On 23 July, at the end of Poincaré's state visit, Buchanan's report to Nicolson was still largely devoted to Anglo-Russian differences over Persia, French efforts to overcome these and hopes of a new Convention. Poincaré and the French team 'seem to have discussed the whole question at length' with Sazonov and were 'quite satisfied with what he told them', so Buchanan concluded, 'The present is, I think, a propitious moment for trying to settle all these outstanding questions...' As to the Balkans situation, Buchanan felt Sazonov would 'make no difficulties' if Austrian demands on Serbia were moderate; although, if Vienna adopted 'an aggressive attitude towards Servia, Russia will sooner or later be forced to intervene in one way or another.' Buchanan was no more specific than this, however, and also reported on 'a series of very bad strikes during the week.' The letter, written on the day Austria delivered its fatal ultimatum to Serbia, barely hinted that war might be imminent. ${ }^{25}$

\section{The Crisis begins, 18-24July}

It was not that Buchanan was unaware of potential problems. On 8 July, Grey had expressed fears to Ambassador Benckendorff of a possible Austrian 'démarche with regard to Servia' and worried that leaked reports about tentative Anglo-Russian naval conversations could 'lead the German authorities to think that some coup was being prepared against Germany. ${ }^{, 6}$ But little happened on an Anglo-Russian plane until ten days later when, in conversation with Buchanan, Sazonov expressed 'great uneasiness' over Austro-Serbian tensions, warning, 'anything in the shape of an Austrian ultimatum at Belgrade could not leave Russia indifferent, and she might be forced to take some precautionary military measures. ${ }^{27}$ Grey hoped such escalation could be avoided, telling Buchanan, 'If Austrian demands in [sic] Servia are kept within reasonable limits... I hope every attempt will be made to prevent any breach of 
the peace'; the ambassador might suggest, 'Austria and Russia should discuss things together if they become difficult. ${ }^{28}$

Buchanan, along with other ambassadors, had met Poincaré briefly at the Winter Palace during a diplomatic reception on 21 July. The Frenchman - rather like Maugham - found the British envoy 'exquisitely courteous if a little cold. ${ }^{29}$ Poincaré had already discussed Persia with the Tsar and said the Russians were prepared to address their differences with Britain. More significant in the immediate term, Buchanan told Poincare of an earlier conversation with the Serbian minister, Miroslav Spalajković, who feared Austria 'would create some incident' to justify an attack on his country. This helped set the scene for a tense encounter that immediately followed. between the President and the Austro-Hungarian ambassador. Buchanan's report to London adds that Poincaré was opposed to bilateral Austro-Russian talks on the Balkans, feeling these 'would be very dangerous at present'. Frustratingly, the President's reasons for believing this are unstated, but it scotched Grey's suggestion of such talks. Poincaré said he preferred to see 'moderating counsels by France and England at Vienna', thereby revealing a desire to draw Britain onto the Russian side in diplomatic exchanges. Later, Buchanan talked to Sazonov, who also wanted the three entente powers 'to counsel moderation at Vienna. ${ }^{, 30}$ A French telegram reveals Buchanan had said Britain would support a demarche in Vienna - an indication, perhaps, of his readiness to stand by the entente during the crisis. ${ }^{31}$ In London, however, there was scepticism, even from pro-entente officials, about putting pressure on Austria. Crowe felt it was 'for the German government to do this' and Nicolson that it 'would be resented and would do harm.' ${ }^{32}$ But Russian and French pressure on Britain for joint action would continue over the coming days. As Otte comments, this 
was far from unprecedented: St. Petersburg and Paris had long sought 'to bind London more firmly to the Franco-Russian alliance and the idea of joint diplomatic initiatives had been their preferred policy tool during previous Balkan crises. ${ }^{33}$

While Russian leaders did not seek war over the following days, their concern over national prestige and growing suspicion of Germany made them determined to show resolve, primarily through mobilisation - a dangerous tactic that increased the danger of war. ${ }^{34}$ On Friday morning, 24 July, Buchanan was 'musing on all that I was going to do during my approaching holiday', when he was telephoned by Sazonov, who had seen the text of the Austrian ultimatum to Serbia, feared its harsh demands 'meant war' and asked to the Ambassador to meet at the French embassy. Here, Sazonov and Paléologue emphasised that, during the state visit, they had re-affirmed their alliance, established a 'perfect community of views' on international problems and agreed to counsel Vienna against any demand amounting to 'an attack on [Serbia's] sovereignty...' Sazonov, who had evidently on a hard line against Austria, then pressed Britain to show 'solidarity with France and Russia' in the face of Vienna's 'immoral and provocative demands', while Paléologue 'gave me to understand that France would not only give Russia strong diplomatic support, but would, if necessary, fulfil all the obligations imposed on her by the alliance.' Faced by such pressure, Buchanan remained calm. He 'could personally hold out no hope that [Britain] would make any declaration of solidarity that would entail engagement to support France and Russia by force of arms', especially since Britain had 'no direct interests in Servia', and bluntly asked if Russia was contemplating war. Sazonov replied this could only be decided after discussion in the Council of Ministers, but 'thought that Russia would at any rate have to mobilise.' 
After lunch, Sazonov and Paléologue continued to press Buchanan 'to declare our complete solidarity with them', the Frenchman insisting that 'a firm and united attitude was our only chance of averting war'. From Paléologue's language, 'it almost looked as if France and Russia were determined to make a strong stand even if we declined to join them.' Buchanan, suggested to them, that Grey might press Vienna and Berlin about the 'danger to European peace of an Austrian attack on Serbia', including a statement that this 'would in all probability force Russia to intervene, that this would bring Germany and France into the field and that, if war became general, it would be difficult for England to remain neutral. ${ }^{35}$ Douglas Newton believes that, in saying this, Buchanan showed he 'clearly sympathised with Sazonov and Paléologue. ${ }^{36}$ In contrast, Luigi Albertini thinks 'Buchanan's language was... temperate and conciliatory', and Grey ought to have taken up his idea of giving 'Vienna and Berlin a warning of the consequences which a war with Serbia might... bring in its train. ${ }^{37}$ Sean McMeekin, too, judges that, if Grey had followed Buchanan's advice on issuing a warning to Germany, Berlin 'would have been under no illusions about British neutrality' and might have dissuaded Austria from declaring war on Serbia. ${ }^{38}$ But Otte argues that, at this point, Grey was focused on persuading Berlin, by friendly advice rather than threats, to restrain Vienna; Grey also warned the German ambassador that any extreme Austrian action would provoke a Russian response..$^{39}$

Buchanan's telegram did have some effect on thinking in London, however. A copy was sent by Prime Minister Henry Asquith to his confidante Venetia Stanley, 'because it shows... how even at this stage Russia is trying to drag us in. ${ }^{40}$ Ministers 
received a copy and, according to one, in Cabinet, Grey, 'in his own quiet way' said it raised the issue of whether Britain should stand by its entente partners. ${ }^{41}$ On his copy, Lewis Harcourt, the Colonial Secretary, underlined those sentences where Buchanan suggested 'it would be difficult for England to remain neutral... ${ }^{42}$ Meanwhile, in the FO, Crowe used the telegram to insist that, with France and Russia determined to stand up to Germany, what mattered was to deter Berlin from war by giving the impression Britain might fight. Crowe agreed with Sazonov that, 'sooner or later England will be dragged into war if it does come.' To this, Nicolson added - his logic strikingly close to Buchanan's - 'Our attitude during the crisis will be regarded by Russia as a test and we must be most careful not to alienate her. ${ }^{43}$ As Otte points out, the problem is that, in relying on what Buchanan reported about strong French support for Russia, the FO relied in turn on how Paléologue interpreted his country's policy. But the French ambassador was something of a maverick, who did not accurately reflect the moderate line Paris wanted or report home fully on the Russian preparations for war. ${ }^{44}$

Grey was content with Buchanan's performance in the 24 July meetings, saying he had spoken 'rightly in very difficult circumstances' and adding, 'I do not consider that public opinion here would... sanction our going to war in the Servian quarrel.' The Foreign Secretary had registered Buchanan's mention of military preparations, however, noting it was 'almost inevitable that in [a] very short time Austria and Russia will both have mobilised against each other.' In such circumstances, Grey now told Buchanan the best option for peace was talks between the other four Great powers - Britain, German, France and Italy - to explore a settlement. It was vital Germany should take part, as an ally of Austria, so that 
mediation seemed impartial. Meanwhile, Austria and Russia, if they mobilised, should not send troops across their borders. ${ }^{45}$ This last point was, as Albertini says, 'a most dangerous thing to say. Instead of restraining St. Petersburg, this was the very thing to drive it forward.' It undermined Buchanan's cautious line towards Sazonov and failed to recognise the danger of a violent German response to any Russian mobilisation. ${ }^{46}$ But Grey, who was no military expert, evidently failed to realise the implications of mobilisation, believing it to be more important that armies, once mobilised, did not invade their neighbours. He was clearly also unwilling to deter Germany by aligning closely with Russia and France. His failure to take such a step was taken up, both by the Conservative opposition at home and by later historians, who argued (like Sazonov) that a stark warning to Berlin might have deterred it from risking war. ${ }^{47}$

\section{War Preparations, 25-28 July}

On the 25th, Buchanan was again invited to meet with Sazonov and Paléologue, describing this as having 'resumed our conversation of the preceding day. ${ }^{48}$ Sazonov said he was willing to see efforts by Britain, France, Germany and Italy with a view to finding a peaceful settlement (and he seems to have come up with this idea independently of Grey.) Nonetheless, ominously, he warned that an order had been drafted for mobilisation and, while this would only be published if it became necessary, 'preliminary preparations for mobilisation would... begin at once.' Buchanan hoped Russia would not mobilise before Grey had a chance to work for peace and reasoned Britain could best play the 'role of mediator at Berlin and Vienna to better purpose as [a] friend who, if her counsels of moderation were disregarded, might one day be converted into an ally, than if she were to declare herself Russia's ally at once.' But Sazonov replied that Germany was counting on British neutrality, 
Austria aimed at establishing hegemony in the Balkans at Russia's expense and, 'If we took our stand firmly with France and Russia there would be no war.' Paléologue also urged British support. Sidestepping these arguments, Buchanan - with what one of his diplomatic colleagues later called 'prophetic foresight' ${ }^{49}$ - warned that, if Russia mobilised, Germany would not give her time to carry this out, 'but would probably declare war at once.' In this, he certainly showed more prescience than Grey. But Sazonov, assured by Paléologue of French support, seemed ready to take the risk and Buchanan warned Grey that London might soon have to 'choose between giving Russia our active support or renouncing her friendship. If we fail her now we cannot hope to maintain that friendly cooperation with her in Asia that is of such vital importance to us ${ }^{50}$ Buchanan's account is ambiguous as to whether this was his own conclusion or whether, during the meeting, Sazonov had made a threat on these lines. ${ }^{51}$ If the Russian did make the threat it was, as Keith Wilson says, 'bleak blackmail’.52

This telegram showed Buchanan was aware of the dangers presented by Russian mobilisation, including the possibility it might provoke war, and clearly warned London that pre-mobilisation measures were being taken. However, he may also have under-emphasised his sympathy with the Franco-Russian case. According to Paléologue's (admittedly, sometimes unreliable) memoirs, when warned by the Frenchman of German ambitions, Buchanan, 'with a weary smile' declared, 'You know you are preaching to the converted. ${ }^{53}$ In his telegrams to Paris, Paléologue regularly failed to mention Buchanan's cautious advice, instead emphasising his sympathy for the entente. ${ }^{54}$ But Buchanan's moderation was undermined in other ways, not least - ironically - by Grey. That morning Count Benckendorrf, had pressed 
the Foreign Secretary to 'give some indication to Germany... we would not stand aside if there was a war', to which Grey replied that he had spoken to the German ambassador 'on the assumption that Russia would mobilise...', adding, 'In effect, I was asking that, if Russia mobilised against Austria, the German government... should ask Austria to consider some modification to her demands...' Once Benckendorff reported this home, the Russian government could only feel Grey approved mobilisation. ${ }^{55}$ Nonetheless, Buchanan's report had some positive impact. Sazonov's willingness to approve four-power talks led Nicolson to put make practical preparations for these, by preparing telegrams to the major European capitals. ${ }^{56}$

There can be no doubt Buchanan was well-disposed to the Russian case. On 26 July, he advised Grey that any parliamentary statement he made should 'show that if European peace in being endangered it is not Russia but Austria that is at fault.... ${ }^{, 57}$ Yet Grey ignored this advice when addressing the House of Commons on 27 July, instead focusing on the need for four-power talks to avoid 'the greatest catastrophe that has ever befallen the continent of Europe... ${ }^{58}$ Nevertheless, Buchanan continued to follow his instructions to try to moderate Russian behaviour. On 26 July, he told Sazonov that, if Britain openly sided with Russia and France in the crisis, it would merely stiffen Germany's attitude and lessen the chances of her restraining Austria. The Ambassador added that, to give Grey time for his peace efforts, Russian mobilisation should 'be deferred as long as possible...' and, if it began, Russian troops should be held on their side of the border. Once again, Sazonov urged Britain to proclaim 'solidarity with France and Russia' and he warned that the order for mobilisation might be given on the day Austria invaded Serbia. ${ }^{59}$ But the changeable Russian also showed some interest in negotiation: on 27 July, Paléologue told 
Buchanan that Sazonov was thinking, again, of direct talks with Austria. ${ }^{60}$ Later that day, Buchanan himself found Sazonov 'very conciliatory and more optimistic', talking about a possible Austro-Serb settlement. ${ }^{61}$

McMeekin's criticises Buchanan for his supposed failure, around 26-27 July, to report clearly on Russian mobilisation: 'Grey did not believe himself to be lying when he kept denying that Russia was mobilising. He had little to go on beyond the reports of his ambassador...' But such criticisms seem mis-directed. For example, McMeekin claims that, on 26 July, when reporting on military preparations in St. Petersburg and Moscow, Buchanan believed these might simply be linked to strike activity. ${ }^{62}$ In fact, after reporting the two regions to be in a 'state of extraordinary protective activity', he simply said this was 'ostensibly in view of strikes', before adding, 'Strikes here are practically over and measure is doubtless connected with intending mobilisation. ${ }^{63}$ McMeekin also complains that, in his evening report of 27 July, Buchanan failed to mention mobilisation. ${ }^{64}$ But the Ambassador's morning telegram had already mentioned the possibility of full mobilisation and warned when it was likely to take place. Furthermore, as seen above, Buchanan had reported 'preliminary preparations' for mobilisation were already taking place. Indeed, by 27 July, British national daily newspapers openly reported that Russia was mobilising five corps. ${ }^{65}$

British officials, then, were hardly in ignorance of Russia's military preparations. It has been seen that Grey accepted Russia would mobilise and even told Benckendorff this. Nicolson warned the German ambassador on 25 July, it would 'be difficult and delicate for us to ask Petersburg not to mobilise at all... when Austria 
was contemplating such a measure... ${ }^{66}$ Now, with a greater sense of the dangers, Crowe minuted - on Buchanan's morning telegram of 27 July - that Russia could not delay mobilising when this 'can only become effective in something like double the time required by Austria and by Germany.' This was the case even though he knew that, 'If Russia mobilizes, we have been warned that Germany will do the same and as German mobilization is directed almost entirely against France, the latter cannot possibly delay her own...' With Vienna apparently bent on war, 'it would be neither possible nor just... to make any move to restrain Russia from mobilizing. ${ }^{97}$ On the basis of Buchanan's reports, military planners also understood what was afoot. On 25 July, General Sir Henry Wilson, the Director of Military Operations, met Nicolson, who 'showed me a despatch just in from Buchanan... [which] said that Russia would not tolerate Austria attacking Servia and would go to war to prevent it. ${ }^{68}$ Grey later explained that, in addition to recognising that Russian mobilisation would be slower than Germany's, he feared, 'if we put pressure on Russia to keep the peace, she might answer "will you support us, if it comes to war?" And - to that question - he could not have given an affirmative answer., ${ }^{69}$

\section{War begins, 28-31 July}

On 28 July, Nicolson penned a long letter to Buchanan. On the one hand, this complained about Sazonov's rapid shifts of position on peace initiatives: over the last few days he had alternatively supported four-power talks, an Anglo-Italian mediation attempt and direct Austro-Russian negotiations. On the other hand, Nicolson could 'quite understand Russia not being able to permit Austria to crush Servia' and 'foresaw as well as you did that this crisis might be taken by Russia as a test of our 
friendship'; so, 'were we to disappoint her all hope of a friendly and permanent understanding with her would disappear.' While the British government could not yet 'give any decided engagements', it had signalled to Berlin and Vienna that they could not bank on British neutrality. (He was particularly thinking of the decision to keep the main British battle fleets together after a trial mobilisation.) He ended by praising Buchanan for his 'usual skilful and tactful manner' in handling 'a most difficult situation' ${ }^{70}$ The letter suggested that, while not completely happy with Sazonov, London might yet take Russia's side in war.

That same day, as Buchanan later recalled, 'things took a decided turn for the worse.' Although Sazonov was planning to meet the Austrian ambassador, he returned to his earlier pessimism, again warning Buchanan that, on the 'day that Austria crossed Servian frontier order for mobilization against Austria would be issued.' He again insisted, the 'only way to avert war was for [the British government] to let it be clearly known that they would join France and Russia. ${ }^{71}$ On leaving Sazonov's office, Buchanan met Paléologue and asked him to argue against any provocative Russian military steps. Significantly, Buchanan's logic was that, 'unless convinced that the whole responsibility for the war rested with Germany, British public opinion would never sanction our participation in it. ${ }^{72}$ Nonetheless, despite the strong hint here that he favoured British intervention in war, Buchanan's was still urging caution. Gordon Martel writes that, while he favoured a Russian alliance, he was 'an experienced diplomat... careful not to encourage the Russians to believe that they could rely on British support under any circumstances. ${ }^{73}$ Bernadotte Schmitt, too, felt Buchanan consistently sought to restrain Russia: 'Very little comfort indeed was M. Sazonov able to get out of Sir George Buchanan. ${ }^{74}$ But the situation became 
much more difficult when, later that day, Austria declared war on Serbia. Buchanan quickly reported Russian infantry were 'leaving Warsaw for frontier. ${ }^{75}$ Crowe was deeply concerned, warning, 'Unless the Russians now decide to pull away... we shall have the general war upon us very soon. ${ }^{76}$

On 29 July, Buchanan reported that Russia had ordered partial mobilization against Austria, though the situation did not seem hopeless. Sazonov told the Ambassador general mobilization had been avoided for fear of sparking a German response, troops would not immediately cross the border and four-power consultations could proceed. Buchanan himself defended Russian behaviour when he met the German ambassador, Count Friedrich Pourtalès, insisting, 'If Russia had not shown that she was in earnest by ordering mobilisation, Austria would have believed that she could go to any lengths..., ${ }^{77}$ Actually, at this point Buchanan may have been misled by Sazonov, who knew general mobilisation (against Germany as well as Austria) was being seriously considered by his government, and who probably, as Fay says, "wished to avoid alarming and alienating British opinion. ${ }^{78}$ Then again, there was considerable confusion in St. Petersburg on 29 July about whether to initiate a general mobilisation, or merely a partial one, and Sazonov himself may not have grasped that mobilisation would likely mean war. ${ }^{79}$ But in London, again, the government was aware of the danger. According to the education minister, Jack Pease, Grey told the Cabinet on 29 July, 'he would continue to urge mediation by as many Powers as he could - and restrain Russia who was mobilising from doing so opposite the German frontier. ${ }^{90}$ Harcourt's journal shows Buchanan's reports were noted carefully in Cabinet: 'Russia has s[ai]d she will mobilise if Austria declares war - before end of Cab. we heard Russia had mobilised in cert[ain] towns on her 


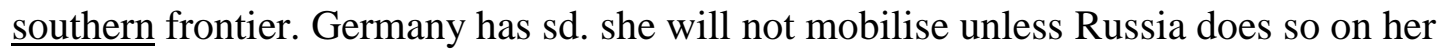
Western frontier. ${ }^{81}$

Events now moved rapidly. Around lunchtime on 30 July, Sazonov called in Buchanan and Paléologue, accused Germany of preparing for war and reported on two meetings with Pourtalès. In the first, the previous afternoon, 'High words were exchanged on both sides' over Austrian intentions; in the second, at 2 a.m., the German 'broke down completely', but Sazonov suggested a possible peace formula: Russia would end its military preparations if Austria agreed to 'eliminate from her ultimatum points which violate [Serbian] sovereignty...' There are difficulties with Sazonov's record at this point. First, he had actually held four meetings with Pourtalès since the afternoon of 29 July; only in the fourth, on the morning of $30 \mathrm{July}$, did he write down the proposed peace formula. ${ }^{82}$ Second, the assertion that Germany was actively preparing for war is contestable: Berlin had not ordered mobilisation and its pre-mobilisation measures were arguably equivalent to preparations Russia had been making for several days. But, criticisms of Buchanan can also be made at this point. McMeekin, who thinks Sazonov's arguments were designed to justify Russian mobilisation, emphasises that, 'If Buchanan had any suspicions about what Sazonov was up to, he failed to express them - or report them to London. ${ }^{93}$ Fay makes the telling point that, in contrast to his earlier pressure for restraint, Buchanan 'evidently made no effort to deter Sazonov from... general mobilization; his failure to do so must have been an encouragement to the Russian Minister., ${ }^{84}$

The Russians ordered general mobilisation later that day. Again, Henry Wilson's diary shows London was kept well informed by Buchanan. On 30 July, he 
recorded, 'war seems to be inevitable. Sazonov and the German ambassador fell out last night and the German went to Sazonov's house at 2 a.m. this morning in tears and said all was over. ${ }^{, 85}$ True, Sazonov continued to give the impression he favoured peace. On 31 July, following a last-ditch plea from Grey, he gave Buchanan and Paléologue a revised peace formula, saying peace talks might begin if AustriaHungary did not let its forces march beyond Serbia's capital, Belgrade, recognised the issue was 'of European interest' and respected Serbian sovereignty. ${ }^{86}$ By then, however, the crisis was moving beyond his control. Around 11 p.m., Pourtalés warned Sazonov that, if Russia did not halt its mobilisation by noon the following day, Germany would also mobilise. ${ }^{87}$

As European war broke out, real criticisms can be made of Buchanan's reporting, both in its promptness and accuracy. Until 28 July, despite his pro-Russian leanings, he had tried, in contrast to Paléologue, to moderate Russian behaviour and reported the main policy decisions soon after they occurred. But, his failure to ask serious questions about Sazonov's claims during their 30 July meeting was, perhaps, an early indication that he now simply backed Russian war preparations. Two more episodes quickly followed, which together call into question his objectivity. First, Buchanan's telegram reporting Russian general mobilization was only received in the FO at 5.20 p.m. on 31 July, almost 24 hours after the order was issued. This short telegram focused on the Russian government's reasoning, 'Austria is determined not to yield to intervention of powers and... is moving troops against Russia as well as against Servia. Russia has also reason to believe that Germany is making active military preparations...' Before it arrived, London had already learnt of the mobilization from - embarrassingly - the Germans. A footnote in the official volume 
of British Documents on the crisis, thinks it 'most improbable' he would have waited so long to report such an important event and suggests the date of despatch on the telegram is a day late. Such a mistake, it argues, could have been made by the clerk who copied the message (the original cyphered telegrams being routinely destroyed). Furthermore, delays in transmission became frequent late in the crisis, when telegrams from St. Petersburg were sent via Aden, other routes being deemed unreliable. $^{88}$

Albertini, however, after a detailed survey of the evidence, believed Buchanan probably did send the telegram on 31 July - after all, that is what date on the telegram says - and pointed out that the British military attaché was equally tardy, only sending his report about general mobilization during the afternoon of 1 August, even though mobilization notices had been publicly posted around St. Petersburg from 4 a.m. on 31 July. Given Paléologue's similar failure to report mobilisation quickly, Albertini raises the possibility there was 'a conspiracy of silence between the representatives of the Triple Entente at St. Petersburg in regard to Russian general mobilization. ${ }^{89}$ Less conspirational is William Jannen's opinion: 'Buchanan was never a man to move fast' and may simply have acted 'with his usual lackadaisical nonchalance'. ${ }^{90}$ As Otte argues with regard to Paléologue's delay, a telegram could have been sent much more quickly: 'Given that the red notices had been plastered all over St. Petersburg it was scarcely a secret, and there was no need now even for encyphering the telegram. ${ }^{91}$ The same point could be made about Buchanan. He might easily have sent an uncyphered telegram directly to London, given mobilization was open knowledge in Russia and he well knew that Germany might react violently to it. 
Certainly, other telegrams got through quickly: one of 31 July was sent from St. Petersburg at 9.23 a.m. local time and arrived in London at 10.15 a.m.; one of 1 August was sent at 7.30 a.m., arriving at 8.40 a.m. ${ }^{92}$ Furthermore, the editors of the British Documents are inconsistent with their arguments about telegrams going via Aden: a later footnote say this route was only used from 1 August. ${ }^{93}$ There is also another example of Buchanan's reporting being suspiciously slow at this time. On the morning of 1 August, he and Paléologue had another meeting with Sazonov, who reported on meetings with the German and Austria ambassadors, which led Buchanan to conclude, 'there now seems no chance of averting a general war unless German and France would agree, as Russia is ready to do, to keep their troops mobilised on their side of the frontier pending final attempt... at settlement.' Yet this report was not even dispatched until 7.30 a.m. the following day. ${ }^{94}$ Buchanan's two telegrams and the Military Attaché's message do indeed suggest a pattern of slow reporting from St. Petersburg at a pivotal moment.

The second episode that suggests Buchanan was, at the very least, dilatory in his duties, concerns his handling of a last-minute British bid for peace. About 1 a.m. on 1 August, following a disturbing midnight communication from the German embassy in London about how Russian mobilisation could provoke war, Asquith went to Buckingham Palace and had King George V approve a message to the Tsar, asking him - in rather convoluted terms - to 'remove the misapprehension which I feel must have occurred, and to leave still open grounds for negotiation and possible peace.' The message was sent via Buchanan, who was instructed 'at once [to] apply for an audience. ${ }^{95}$ Although it was dispatched from London at 3.30 a.m., he claimed not to have received it until 5 p.m., an unusually long delay. Albertini admits this probably 
made no difference: 'it could not have arrived in time for Buchanan to read it decoded, to request and obtain an audience, make the journey to the Peterhof [palace], and be received by the Tsar before 11 a.m.', the latest time when it might have made a difference. (The German ultimatum to Russia to halt its mobilisation expired at midday.) Nonetheless, Albertini feels Buchanan 'did not treat this important document with the urgency it deserved' and ought to have sought an audience more rapidly. Furthermore, the Ambassador was inordinately slow in forwarding the Tsar's reply to London: he had received this by about 2 a.m. on 2 August, but only sent it at 3.10 p.m., that is more than twelve hours later. It arrived in London at 5.15 p.m., by which time continental war was unavoidable and debate focused on whether Britain should forcefully intervene. Albertini makes the intriguing argument that Buchanan, who had previously 'endeavoured to restrain Sazonov from military measures', was now behaving very differently: he may even have delayed the Tsar's message, 'lest it should adversely influence the decisions of his own country, of which he felt none too sure.' 96

Buchanan's contemporary account, sent to Nicolson, claims attempts to arrange an audience began 'at once', but concedes he waited to receive a draft reply written up by Sazonov, before seeing the Tsar. Then, arriving at the Peterhof about 10.45, Buchanan told the Tsar the draft reply was 'couched in too official language', so time was spent discussing the situation before the pair re-drafted it. Buchanan claimed he "virtually had to dictate the telegram... on the lines of the draft which Sazonow had given me and on what His Majesty told me.' It all meant he was not back at the embassy until 2 a.m. ${ }^{97}$ Buchanan's memoirs add that Sazonov had brought the initial draft to the embassy at 8 p.m., having already informed the Ambassador by 
telephone about Germany's declaration of war. Buchanan left the embassy at 9 p.m. but, 'owing to something having gone wrong with the electric lights on my motor, the chauffeur took a wrong turn', hence their late arrival at the Peterhof. Why, after returning to the embassy, he took so long to send the message off is simply left unexplained. $^{98}$

The Tsar's reply to King George, shaped by Buchanan, claimed 'I would gladly have accepted your proposals' had Germany not declared war; Russia 'had devoted all her efforts to finding some pacific solution', but Austria was determined 'to crush Servia.' The Tsar had initially ordered a partial mobilisation, but was 'compelled' to turn this into a general one because 'of complete Austrian mobilisation, of the bombardment of Belgrade, of concentration of Austrian troops in Galicia, and of secret military preparations being made by Germany.' The Tsar insisted 'mobilization did not necessarily entail war...', but hoped Britain would 'support France and Russia in fighting to maintain balance of power in Europe.' Exactly how much of this was Buchanan's work is difficult to guess, but he suggested no disagreement with any of it. He even added his own note, asserting, 'if we do not respond to [the] Emperor's appeal for our support, we shall at the end of the war... find ourselves without a friend in Europe, while our Indian Empire will no longer be secure from attack by Russia.' This was very much in line with arguments Buchanan and Nicolson had made before the July crisis broke. ${ }^{99}$ Even Schmitt, usually a defender of the entente case, had to admit this message was 'not altogether correct' and that Russia acted before 'complete Austrian mobilisation', while the Tsar and Buchanan may have been 'trying to make out as strong a case as possible for Russia...' ${ }^{100}$ Newton, who feels there was a general British failure to restrain Russia 
during the crisis, accuses Buchanan of 'stunningly imposing his own choices upon national decision-making', by helping write the reply to George V. ${ }^{101}$

It is possible that swifter reporting from St. Petersburg, especially if it had suggested Russia was behaving in a bellicose manner, might have influenced British decision-making. Not everyone in London shared the Buchanan-Nicolson outlook. The backbench Liberal Foreign Affairs Committee sent a resolution to Grey on 29 July arguing that, 'if both France and Russia were informed that on no account would we be drawn into war even though they and other European powers were involved it would have a moderating effect on their policy. ${ }^{, 102}$ Lord Morley, one of two Cabinet ministers who resigned over the war, gave as his reason that, 'To swear ourselves to France is to bind ourselves to Russia...' He feared a victory for the entente would leave Russia 'pre-eminent in Europe... Will that be good for Western civilisation? I don't think so.' ${ }^{103}$ Horace Rumbold, the chargé d'affaires in Berlin, had 'little patience with the Austrians and Russians ... the former were always d-d fools, the latter untrustworthy barbarians'; while Francis Bertie, the Ambassador to France, noted, 'I cannot believe in war unless Russia wants it. ${ }^{104}$ More important, there are signs Grey himself was not totally committed to Russia. Harcourt records that, in Cabinet on 31 July, Grey said he would get Germany to pressurise Austria 'to make some reasonable offer to St. Petersburg and then if Russia proved unreasonable it might give us ground to wash our hands of Russia... ${ }^{105}$ Following this, in the socalled 'misunderstanding' of 1 August, Grey apparently raised with the German ambassador the possibility of Britain and France remaining neutral in the war, leaving Russia to fight alone. ${ }^{106}$ 
By now, however, Buchanan seems to have been primarily interested in defending the Russian case. After all, as he had told Paléologue a few days before, 'unless convinced that the whole responsibility for the war rested with Germany, British public opinion would never sanction our participation in it. ${ }^{107}$ On 3 August, he wrote to Nicolson, reviewing the crisis. From the outset, the Russians 'took up a firm attitude and made it perfectly clear that they would not allow Austria to crush Servia', Paléologue showed 'Russia could count on the support of France' and Sazonov's 'anxiety had been what England would do.' In contrast to Russia's supposed reasonableness, there was 'strong evidence to show that Germany really desired war, or at all events the disruption of the Triple Entente, which must have followed a failure on our part to support Russia.' Buchanan summed up his own aim as having 'been to dissuade [Sazonov] from doing anything to precipitate a conflict, so as to allow time for us and the other Powers to mediate; and if our efforts to maintain peace have failed it is in no way his fault.' Buchanan made clear his own views of the policy London should adopt, in emotional terms:

I only pray that England will prove true to herself and to her friends, as if she deserts them in their hour of need she will find herself isolated after the war; and the hours of our Empire will be numbered.

Since he knew this letter might take days to reach London, it seems designed to put on record his own interpretation of events, defending Russia, blaming war on Germany and evading detailed questions about the timing and significance of Russian mobilisation. ${ }^{108}$

\section{Conclusion}


Buchanan later recalled, in 'the first three days of the war my position was not a pleasant one.' His daughter, Meriel, found 3 August particularly difficult. 'From the early morning till late at night people kept... coming to ask what England meant to do. Everybody is getting frightfully anxious about it and they all say that if they don't settle soon there will be really serious rows.' Meriel had absorbed Sazonov's argument, soon to become a staple criticism of Grey's behaviour during the crisis: If England from the beginning had been absolutely firm and said decidedly that if there was a war she would take part with Russia, Germany might not have had the courage to move in the way she has and the whole thing might still possibly have been averted. And England is bound to be dragged in at the end and it would serve her right if she was utterly defeated. ${ }^{109}$

The following day, Britain was indeed 'dragged in' and, as Newton points out, the FO minimised uncomfortable questions about Russian policy and Buchanan's behaviour. Officials doctored telegrams from Buchanan when compiling the White Paper on the crisis, to remove evidence that Sazonov and Paléologue had urged Britain to fight, emphasise Sazonov was open to peace talks and minimise evidence of the Ambassador's desire for entente solidarity. ${ }^{110}$

How, then, should Buchanan's performance during the July Crisis be judged? Until Poincaré's state visit, the Ambassador was focused on preparing for a possible re-negotiation of the Russian entente. He may be criticised for this, but it was a fault shared with some key officials at home, like Nicolson. In any case, Europe in general was taken aback by the scale of demands Austria made against Serbia on 23 July. Over the following days, Buchanan has generally been praised for resisting the joint 
Franco-Russian pressure on Britain, which itself seems to have been decided during Poincare's state visit. There is something to be said for Fay and Barnes' case that Buchanan preached caution, only to be undermined by Grey's clumsy acceptance of Russian mobilisation as an understandable, defensive step. Until 28 July, following his instructions, the Ambassador did urge Russia to negotiate, questioned the wisdom of mobilisation and resisted calls from Sazonov and Paléologue for Britain to align with them. His reporting at this point was more complete and honest than the French ambassador's. McMeekin's case that Buchanan's reporting on mobilisation was inadequate around 26-27 July seems unfair. Buchanan may have been no military expert and his reports lacked detail, but Whitehall understood Russia was actively preparing for war, beginning with 'preliminary preparations'. Until 28 July, Buchanan does seem to have shown the qualities of tact, honesty and imperturbability for which he had been chosen for his important post. He also seems to have had a clearer grasp of the implications of mobilisation than many politicians, including Grey and Sazonov. As Otte says, 'Sazonov's deterrence strategy, combining... mediation with military posturing, was deeply flawed. ${ }^{111}$ But Buchanan predicted on 25 July that Russian mobilisation would lead Germany to strike.

Yet, however cold Maugham and Poincaré found him, the Ambassador was not without deep emotions. Before the crisis, he shared Sazonov's logic that Britain should side with its entente partners if Germany were to be deterred; he also feared Britain would have to join in a European war in the end. With such opinions, it is not surprising that he advised Grey, on 24 July, to warn Germany it might be difficult for Britain to remain neutral. Even as he preached caution to Sazonov, Buchanan continued to emphasise to Grey the need to preserve Russian friendship, not least to 
safeguard British interests in Asia. Then, after 28 July, when Austria's declaration of war on Serbia made a conflagration likely, the Ambassador focused on defending the Russian case. True, he may have been deliberately misled by Sazonov, especially in their 30 July conversation about partial mobilisation. Ponting calls Sazonov 'mendacious', while Clark argues that, from 26 July, 'the Russians deliberately concealed the extent of their "clandestine preparations" from... Buchanan..." ${ }^{112}$ But he hardly asked probing questions of the foreign minister and Albertini is surely right to sense that his reporting now became dilatory, perhaps deliberately starving London of information, rather like Paléologue. There may have been excuses for Buchanan's late reporting of Russian mobilisation (it is possible his telegram was held up en route) and the delay in talking to the Tsar on 1 August (his car developing a technical fault) But this hardly explains why he became so slow at drafting messages, readily accepted Sazonov's explanations of Russian policy and adopted a one-sided interpretation of events in his messages home, becoming a virtual apologist for Russia and undermining those in London who might have distanced themselves from her, had they been more fully informed. A possible psychological explanation of this is the so-called 'Rubicon theory': when decision-makers move from a 'deliberative' mindset (when different options are in play) to an 'implemental' one (when the key decision is taken), they tend to focus on a narrow goal - in Buchanan's case ensuring British support for Russia - ignoring information which challenges their case and selecting only that which supports it. ${ }^{113}$

In his memoirs, Buchanan continued to put the best possible light on Russian behaviour, asserting that, 'Though Austria had already begun mobilising against Serbia on the $26^{\text {th }}$, it was only on the $28^{\text {th }}$ that Russia took any preliminary steps for a 
mobilization.' In fact, Russia had been taking preliminary measures since 25 July. He also continued to justify Russia's full mobilisation on the misleading grounds of 'the extensive military operations... Germany was secretly making, as well as of the Austrian general mobilization.' ${ }^{114}$ Part of the responsibility for Buchanan's behaviour in the last phase of the crisis may again lie with Grey, who chose not to be concerned about Russian mobilisation, did not ask the Ambassador for additional information and perhaps, as Clark claims, 'subordinated his understanding of the Austro-Serbian quarrel to the larger imperatives of the entente... ${ }^{115}$ Once the crisis was underway, Grey faced strong pressure from Nicolson and Crowe, as well as Buchanan, to stand by Russia. Then again, as Keith Neilson says, the impact of their advice on the Foreign Secretary 'is uncertain since (he) remained largely aloof from his advisers' at times and became more concerned about Cabinet divisions over intervention. ${ }^{116}$ On 1 August, he even considered a deal to keep France neutral - leaving Russia alone to fight Germany. Viewed in that light, Buchanan may have allowed his own interpretation of British interests to override the imperative faced by any ambassador, to report as fully and accurately as possible on their host government's policies, and so helped push London towards war on Russia's side.

\section{Acknowledgements}

I am grateful to Professor Thomas Otte and the Review's two anonymous readers for their valuable comments on earlier drafts.

\section{References}


${ }^{1}$ J.W. Headlam-Morley (ed), British Documents on the Origins of the War, 1898-

1914, Volume XI (London: HMSO, 1926) [hereinafter BD], document 8.

${ }^{2} B D$, doc. 19 .

${ }^{3}$ Harry Barnes, The Genesis of the World War (New York: Howard Fertig, 1970),

732; Sidney Fay, The Origins of the World War, Volume II (New York: Macmillan, 1936), 380 .

${ }^{4}$ Sean McMeekin, July 1914 (London: Icon, 2013), 238.

${ }^{5}$ M.B. Hayne, The French Foreign Office and the Origins of the First World War (Oxford: Clarendon Press, 1993), 301; Lamar Cecil, The German Diplomatic Service, 1871-1914 (Princeton University Press, 1976), 320; Zara Steiner, The Foreign Office and Foreign Policy, 1898-1914 (London: Ashfield, 1969), 185.

${ }^{6}$ Fiona Tomaszewski, A Great Russia: Russia and the Triple Entente (Westport:

Praeger, 2002), 85-89; Michael Hughes, Diplomacy before the Russian Revolution (Basingstoke: Palgrave, 1999), 140-45.

${ }^{7}$ BD, docs. 132, 177 and 309; Marina Soroka, Britain, Russia and the Road to the First World War: the fateful embassy of Count Aleksandr Benckendorff (London: Ashgate, 2011), 250-56.

${ }^{8}$ Robert Bruce Lockhart, Memoirs of a Secret Agent (London: Penguin, 1950), 116.

${ }^{9}$ Hardinge to Nicolson, 29 March 1911, [Kew, United Kingdom National Archives], F[oreign] O[ffice records] 800/348.

${ }^{10}$ Lockhart, Memoirs, 119 and 153.

${ }^{11}$ Keith Neilson, Britain and the Last Tsar: British policy and Russia, 1894-1917

(Oxford: Clarendon Press, 1995),69-70.

${ }^{12}$ H.J. Bruce, Silken Dalliance (London: Constable, 1947), 173-74. 
${ }^{13}$ Michael Hughes, Inside the Enigma: British officials in Russia, 1900-39 (London: Hambledon Press, 1997), 20.

${ }^{14}$ Somerset Maugham, Ashenden (London: Vintage Books, 2000 edition), 215, 228 and 241 .

${ }^{15}$ For example: Michael Ekstein, 'Great Britain and the Triple Entente on the eve of the Sarajevo Crisis', in F.H. Hinsley (ed), British Foreign Policy under Sir Edward Grey (Cambridge: Cambridge University Press, 1977), 343-48; Zara Steiner and Keith Neilson, Britain and the Origins of the First World War (Basingstoke: Palgrave, 2003), 121-29; Neilson, Tsar, 320-26.

${ }^{16}$ Keith Wilson, The Policy of the Entente (Cambridge: Cambridge University Press, 1985), 74-84; 'Grey', in Wilson (ed), British Foreign Secretaries and Foreign Policy (London: Croom Helm, 1987), 176-83; Wilson, Empire and Continent (London; Mansell, 1987), chapter 9.

${ }^{17}$ Thomas Otte, "A “formidable factor in European politics": views of Russia in 1914', in Jack Levy and John Vasquez (eds), The Outbreak of the First World War (Cambridge University Press, 2014), 89-94.

${ }^{18}$ George Buchanan, My Mission to Russia, Volume I (Boston: Little, Brown, 1923), 138-39.

${ }^{19}$ Buchanan to Nicolson, 18 March 1914, FO800/373.

${ }^{20}$ Zara Steiner, 'The Foreign Office under Sir Edward Grey', in Hinsley, Grey, 24-25.

${ }^{21}$ Keith Wilson, The Rasp of War: the letters of H.A. Gwynne to The Countess

Bathurst (London: Sidgwick and Jackson, 1988), 17.

${ }^{22}$ Buchanan, Mission, 114-17.

${ }^{23} B D$, xi and doc. 49.

${ }^{24} B D$, xi-xii. 
${ }^{25} B D$, doc. 164.

${ }^{26} B D$, doc. 39.

${ }^{27} \mathrm{BD}$, doc. 60 .

${ }^{28} B D$, doc. 67.

${ }^{29}$ Raymond Poincaré, Memoirs, 1913-14 (London: Heinemann, 1928), 170.

${ }^{30} \mathrm{BD}$, docs. 75 and 76; Buchanan, Mission, 188-89.

${ }^{31}$ Documents Diplomatiques Français, 1871-1914, $3^{\text {rd }}$ series, Volume XI (Paris:

Imprimerie Nationale, 1936) [hereinafter $D D F]$, doc. 1.

${ }^{32} \mathrm{BD}$, minutes following doc. 76 .

${ }^{33}$ Thomas Otte, July Crisis (Cambridge University Press, 2014), 205.

${ }^{34}$ See Ronald Bobroff, 'War accepted but unsought: Russia's growing militancy and the July Crisis', in Levy and Vasquez, Outbreak, 227-51.

${ }^{35}$ BD, doc. 101; Buchanan, Mission, 189-92.

${ }^{36}$ Douglas Newton, The Darkest Days: the truth behind Britain's rush to war, 1914

(London: Verso, 2014), 20-21.

${ }^{37}$ Luigi Albertini, The Origins of the War of 1914, Volume 2 (Oxford: Oxford University Press, 1952), 296.

${ }^{38}$ McMeekin, 1914, 279-80.

${ }^{39}$ Otte, Crisis, 144-49.

${ }^{40}$ Michael and Eleanor Brock (eds), H.H. Asquith Letters to Venetia Stanley (Oxford: Oxford University Press, 1982), 125.

${ }^{41}$ Lord Morley, Memorandum on Resignation (London: Macmillan, 1928), 1-2.

42 Note on Buchanan to Grey, 24 July, [ Bodleian Library, Lewis Harcourt Papers] Ms. Eng. c. 8284.

${ }^{43} \mathrm{BD}$, minutes following doc. 101 . 
${ }^{44}$ Otte, Crisis, 261. On Paléologue's conduct see: Irwin Halfond, Maurice Paléologue (Lanham: University Press of America, 2007), chapter 5.

${ }^{45} B D$, doc. 112 .

${ }^{46}$ Albertini, Volume 2, 335-36.

${ }^{47}$ Highlighted in H.H. Asquith, The Genesis of the War (London: Cassell, 1923), 201.

${ }^{48}$ Buchanan, Mission, 195.

${ }^{49}$ Horace Rumbold, The War Crisis in Berlin (Second edition, London: Constable, 1944), 147.

${ }^{50} \mathrm{BD}$, doc. 125 .

${ }^{51}$ Fay, Volume II, 328, believes Sazonov made this threat.

${ }^{52}$ Wilson, Decisions, 184.

${ }^{53}$ Maurice Paléologue, An Ambassador's Memoirs, Volume I, 1914-15 (London: Hutchinson, 1923), 35.

${ }^{54}$ See Otte, Crisis, 250.

${ }^{55} \mathrm{BD}$, doc. 132; Otto Hoetzsch (ed), Internationalen Beziehungen im Zeitalter des Imperialismus, First Series (Berlin, 1931-34), Volume V, doc. 54.

${ }^{56} \mathrm{BD}$, doc. 139.

${ }^{57} B D$, doc. 152 .

${ }^{58}$ House of Commons Debates, Volume 65, columns 938-39.

${ }^{59}$ BD, doc. 170; Buchanan, Mission, 196.

${ }^{60} \mathrm{BD}$, doc. 179 .

${ }^{61}$ BD, doc. 198; Buchanan, Mission, 196.

${ }^{62}$ McMeekin, 1914, 238.

${ }^{63} B D$, doc. 155 .

${ }^{64}$ McMeekin, 1914, 239. 
${ }^{65}$ Manchester Guardian, 27 July.

${ }^{66} B D$, doc. 146.

${ }^{67} \mathrm{BD}$, minute on doc. 170 .

${ }^{68}$ Henry Wilson diary, 25 July, [Imperial War Museum, London].

${ }^{69}$ Temperley notes on meeting with Grey, undated [British Library, Spender Papers], Add[itional] Mss. 46386.

${ }^{70} \mathrm{BD}$, doc. 239.

${ }^{71}$ BD, doc. 247; Buchanan, Mission, 197.

${ }^{72}$ Buchanan, Mission, 197; Paléologue, Memoirs, 39.

${ }^{73}$ Gordon Martel, The Month that changed the World (Oxford: Oxford University Press, 2014), 171-72.

${ }^{74}$ Bernadotte Schmitt, The Coming of the War, 1914, Volume II (New York: Howard Fertig, 1966), 90.

${ }^{75} \mathrm{BD}$, doc. 234 .

${ }^{76}$ Eyre to Clema Crowe, 28 July [Bodleian Library, Crowe Papers], Ms. Eng. d. 2903. ${ }^{77} B D$, doc. 276.

${ }^{78}$ Fay, Volume II, 457-58.

${ }^{79}$ William Jannen, The Lions of July: prelude to war, 1914 (Novato CA: Presidio, 1996), 167 and 179-80.

${ }^{80}$ Keith Wilson (ed), 'The Cabinet Diary of J.A. Pease, 24 July-5 August 1914', Proceedings of the Leeds Philosophical and Literary Society, Vol. 19, No. 3 (1983),

6.

${ }^{81}$ Harcourt Journal, 29 July, Ms. Eng. c. 8269.

${ }^{82} B D$, doc. 302 .

${ }^{83}$ McMeekin, 1914, 300. 
${ }^{84}$ Fay, Volume II, 470-71.

${ }^{85}$ C.E. Callwell, Sir Henry Wilson, Volume 1 (London: Cassell, 1927), 152.

${ }^{86}$ BD, doc. 393; Buchanan, Mission, 203.

${ }^{87}$ Otte, Crisis, 463.

${ }^{88} B D$, doc. 347.

${ }^{89}$ Luigi Albertini, The Origins of the War of 1914, Volume 3 (Oxford: Oxford University Press, 1952), 135-38; BD, doc. 410.

${ }^{90}$ Jannen, Lions, 242.

${ }^{91}$ Otte, Crisis, 454.

${ }^{92} B D$, docs. 332 and 459.

${ }^{93} \mathrm{BD}$, note on doc. 454 .

${ }^{94} B D$, doc. 459.

${ }^{95}$ Brocks, Letters, 139-40; BD, doc.384.

${ }^{96}$ Albertini, Volume 3, 125-32.

${ }^{97} B D$, doc. 665.

${ }^{98}$ Buchanan, Mission, 205-06.

${ }^{99} \mathrm{BD}$, doc. 490.

${ }^{100}$ Schmitt, Volume II, 329-30.

${ }^{101}$ Newton, Darkest, 111.

${ }^{102}$ Ponsonby to Grey, 29 July [National Library of Scotland, Murray of Elibank Papers], Ms.8805.

${ }^{103}$ Morley, Memorandum, 6-7 and 30-31.

${ }^{104}$ Horace to Louisa Rumbold, 29 July [Bodleian Library, Rumbold Papers] Rumbold Dep.16; Lady Lennox, ed., The Diary of Lord Bertie, Volume I (London: Hodder and Stoughton), 2. 
${ }^{105}$ Harcourt Journal, 31 July, Ms. Eng. c. 8269.

${ }^{106}$ Keith Wilson, 'Understanding the "Misunderstanding” of 1 August 1914', Historical Journal, Vol. 37, No. 4 (1994), 885-89.

${ }^{107}$ Buchanan, Mission, 197; Paléologue, Memoirs, 39.

${ }^{108} B D$, doc. 665 .

${ }^{109}$ Buchanan, Mission, 212; Meriel Buchanan diary, 4 August, [Nottingham University, Buchanan Papers], Bu57.

${ }^{110}$ Newton, Darkest, 295-96.

${ }^{111}$ Otte, Crisis, 519.

${ }^{112}$ Clive Ponting, Thirteen Days: countdown to the Great War (London: Pimlico, 2003), 223; Christopher Clark, The Sleepwalkers: how Europe went to war in 1914 (London: Penguin, 2012), 495.

${ }^{113}$ Dominic Johnson and Dominic Tierney, 'The Rubicon Theory of War', International Security, Vol. 36, No. 1 (2011), 7-40.

${ }^{114}$ Buchanan, Mission, 199-200.

${ }^{115}$ Clark, Sleepwalkers, 495-98.

${ }^{116}$ Neilson, Tsar, 339. 